\title{
Menyiapkan Keluarga Berdaya Dasawisma Di Masa Pandemi Covid-19
}

\author{
Dyah Mutiarin 1*, Muhammad Eko Atmojo², Muhamad Heri Zulfikar ${ }^{3}$ \\ 1. Magister Ilmu Pemerintahan, Program Pasca Sarjana, Universitas Muhammadiyah Yogyakarta \\ 2 Ilmu Pemerintahan , Fakultas IImu Sosial dan Ilmu Politik, Universitas Muhammadiyah Yogyakarta \\ 3 Teknik Sipil, Fakultas Teknik, Universitas Muhammadiyah Yogyakarta \\ Universitas Muhammadiyah Yogyakarta - Kampus Terpadu UMY-J. Brawijaya, Kasihan, Bantul-Yogyakarta, 55183, 0274387656 \\ Email: dyahmutiarin@umy.ac.id \\ DOI: $10.18196 / p p m .34 .297$
}

\begin{abstract}
Abstrak
Tulisan ini bertujuan untuk mendeskripsikan dan menganalisis peningkatan kapasitas perempuan di era pandemi Covid-19. Model yang dilakukan adalah dengan meningkatkan kapasitas perempuan sebagai ibu maupun anggota rumah tangga dalam kelvarga berdaya, khususnya di Kecamatan Banguntapan, Bantul, Yogyakarta. Pandemi Covid-19 berdampak pada seluruh aspek kehidupan seperti kesehatan, ekonomi, social dan Pendidikan. Perempuan sebagai subyek pemberdayaan selama ini pun tidak lepas dari dampak Covid-19 sebagai pandemi global sejak Akhir 2019 yang lalu. Metode dalam pemberdayaan meliputi: identifikasi problem, perumusan agenda pemberdayaan, pengambilan keputusan, dan pelatihan peningkatan kapasitas dalam membentuk kelvarga berdaya. Hasil dari peningkatan kapasitas perempuan melalvi kelvarga berdaya ini adalah perempuan mampu mengidentifikasi masalah, merumuskan pemecahan masalah, dan melaksanakan pelatihan dalam kelvarga berdaya melawan Covid-19.
\end{abstract}

Keywords: Peningkatan Kapasitas Perempuan, Keluarga Berdaya, Pandemi Covid-19

\section{Pendahuluan}

Perempuan sebagai subyek pemberdayaan selama ini pun tidak lepas dari dampak Covid-19 sebagai pandemi global sejak Akhir 2019 yang lalu. Perempuan dan keluarga tak terpisahkan. Keluarga merupakan unit terkecil dalam masyarakat yang memiliki fungsi sosial, ekonomi, budaya, kesehatan, serta ketahanan keluarga. Pada saat pandemi covid-19 ini terjadi, secara perilaku sosial, kesadaran keluarga di Indonesia untuk meningkatkan konsumsi sayuran masih rendah. Data Kementerian Kesehatan menunjukkan rendahnya konsumsi sayuran diduga menjadi penyebab utama munculnya gangguan kesehatan mulai dari obesitas, kanker, stroke, penyakit ginjal krinis, diabetes melitus hingga hipertensi. Konsumsi buah dan sayuran masyarakat Indonesia mengacu data BPS 2016 mencapai 173 gram per hari, lebih kecil dari angka kecukupan gizi Badan Kesehatan Dunia (WHO), 400 gram per hari.

Disisi lain, secara finansial, kebutuhan sayuran dalam keluarga lebih banyak disuply dari pasar. Keluarga di Indonesia lebih banyak membeli dari pada menanam sendiri untuk keperluan rumah tangga. Sementara disisi lain, potensi keluarga untuk menyediakan kebutuhan rumah tanga sendiri khususnya sayuran, sangat tinggi. Hal ini karena sayuran dapat ditanam pada lahan yang sempit secara vertical. Apabila tiap keluarga mau menanam sayuran sendiri di rumah, maka substitusi nilai ekonomi finansial rumah tangga dapat dimulai dari keluarga.

Berdasarkan hasil wawancara dengan Dasawisma PKK Maguwo Banguntapan dan observasi Tim Pengabdian Masyarakat dengan mitra bahwa anggota dan Dasawisma PKK Maguwo Banguntapan, tiap keluarga teridentifikasi memiliki potensi tinggi untuk mampu menyediakan sayuran sebagai bahan konsumsi rumah tangga. Pengabdian ini memberi perhatian khusus pada upaya pemberdayaan perempuan khususnya bagi PKK. Dalam kegiatan dasawisma PKK Maguwo Banguntapan sebelumnya, belum pernah diadakan program pembentukan gerakan penanaman sayuran untuk konsumsi rumah tangga, padahal sayuran merupakan kebutuhan masyarakat yang berdaya dan sangat diperlukan untuk kesehatan sebagai upaya menahan dampak kesehatan akibat covid-19. 
Target dari pemberdayaan ini adalah meningkatnya kemampuan Dasawisma dan anggota khususnya terkait kesadaran keluarga menambah nilai ekonomi keluarga dan membentuk keluarga sehat dengan memperbanyak konsumsi sayuran di masa pandemi covid-19.

\section{Metode Pelaksanaan}

Pentingnya memahami metode pengabdian masyarakat tidak terlepas dari core idea pembangunan/pemberdayaan masyarakat yang berbunyi: "Accept the community as they are" and "Begin the community development work, where the community is" (Burton E. Swanson 1988:25).

Dari survei yang dilakukan maka, ada beberapa hal yang dapat dilakukan:

1. Peningkatan wawasan dan pengetahuan terkait pentingnya gerakan Keluarga Berdaya bagi anggota dan pengurus Dasawisma. Hal ini didasarkan pada pertimbangan bahwa mereka adalah seluruhnya para ibu di keluarga dimana memiliki peran penting dalam kesehatan keluarga dan masih lemahnya kesadaran sadar gizi

2. Belum adanya buku panduan terkait Gerakan Keluarga Berdaya

3. Masih minimnya fasilitas penguatan pemenuhan gizi keluarga dasawisma yang dapat dipergunakan untuk mendukung kegiatan dasawisma

Diskusi yang dilakukan oleh Tim Pengabdian UMY dengan Pihak Dasawisma PKK Maguwo Banguntapan telah disepakati program sebagai berikut:

(1) Penyuluhan terkait pentingnya potensi keluarga sebagai sumber nilai tambah ekonomi

(2) Pembentukan Gerakan Keluarga Berdaya

(3) Pendampingan Gerakan Keluarga Berdaya

(4). Pemberian fasilitas hidroponik untuk Gerakan Keluarga Berdaya

Metode yang akan dilaksanakan oleh Tim pengabdian masyarakat ini adalah: (1)

Penyuluhan terkait pentingnya potensi keluarga sebagai sumber nilai tambah ekonomi (2) Pembentukan Gerakan Keluarga Berdaya (3) Pendampingan Gerakan Keluarga Berdaya dalam menggiatkan penanaman sayuran (4). Pembuatan buku Gerakan Keluarga Berdaya.

\section{Hasil dan Pembahasan}

Menurut Hartono dkk ( 2017) keluarga sadar gizi di Indonesia, peningkatan sosialisasi tentang keluarga sadar gizi masih sangat diperlukan. Dalam pemberdayaan ini, langkah pemberdayaan dimulai dengan penyuluhan terkait pentingnya potensi keluarga sebagai sumber nilai tambah ekonomi.

1. Penyuluhan terkait pentingnya potensi keluarga sebagai sumber nilai tambah ekonomi Dalam situasi pandemi covid-19 ini, keluarga dasawisma PKK Maguwo Banguntapan menyadari akan potensi keluarga untuk menjadi agen penggerak ekonomi keluarga yang terpukul akibat pandemi covid-19.

Penyuluhan dilakukan secara tatap muka dengan metode ceramah dan menggunakan alat peraga. Dengan penyuluhan ini diharapkan tujuan penyuluhan tercapai yaitu:

1. Meningkatkan partisipasi keluarga bergerak dalam ekonomi produktif

2. Mensosialisasikan pentingnya pemanfaatan lahan kosong di rumah.

3. Meningkatkan pengelolaan keuangan keluarga

4. Meningkatkan kesadaran akan pentingnya ketahanan dan kemandirian keluarga 


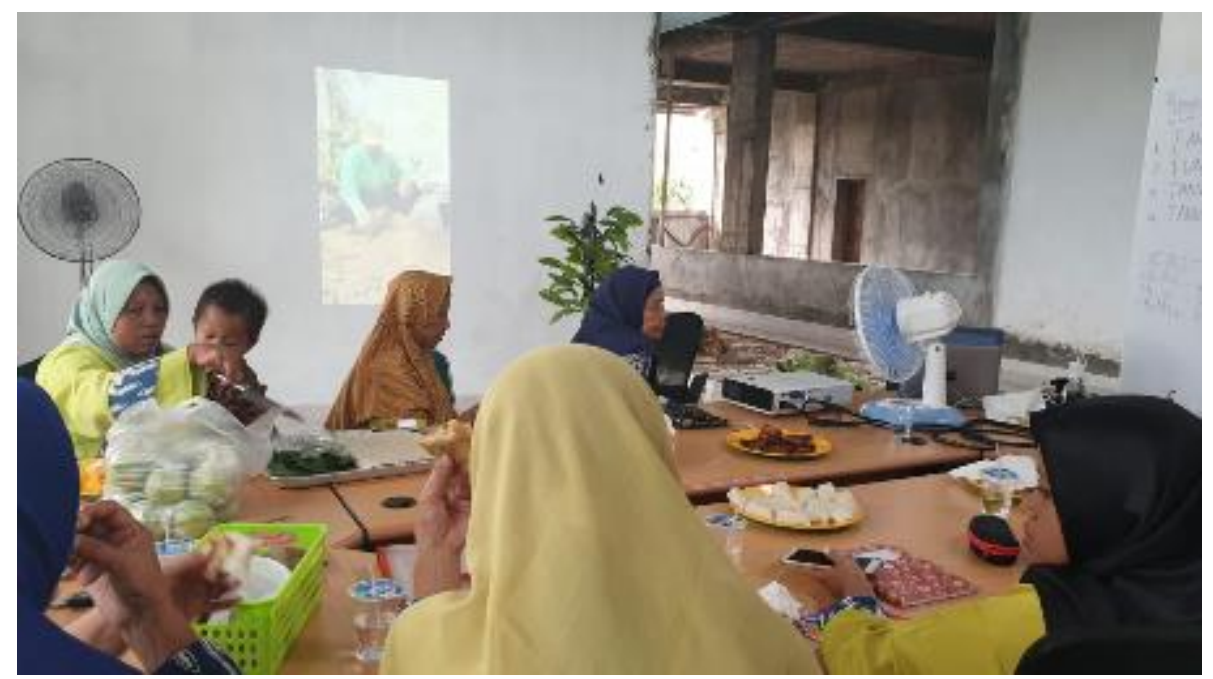

Penyuluhan potensi keluarga sebagai sumber nilai tambah ekonomi (Sumber: dokumen pribadi, 2020)

Adapun materi pelatihan adalah:

a. Identifikasi dampak ekonomi covid pada keluarga

b. Pengenalan potensi dan sumberdaya milik keuarga

c. Pemanfaatan lahan pekarangan untuk ketahanan keluarga

d. Nilai tambah ekonomi

Pelatihan diikuti oleh 25 anggota dasawisma, dan dilakukan dalam program pemberdayaan.

\section{Pembentukan Gerakan Keluarga Berdaya}

Pada 20 Februari 2020, PKK Dasawisma IV Maguwo Banguntapan membentuk Keluarga Berdaya. Adapun tujuan keluarga berdaya adalah;

1. Keluarga mampu mengenali potensi yang ada disekitarnya untuk dijadikan kegiatan produktif.

2. Mengenalkan dunia usaha pada keluarga.

3. meningkatkan kegotongroyongan dan kerukunan antar anggota dasawisma

4. menambah pengetahuan dan ketrampilan menuju ekonomi produktif

5. Meningkatkan ekonomi keluarga

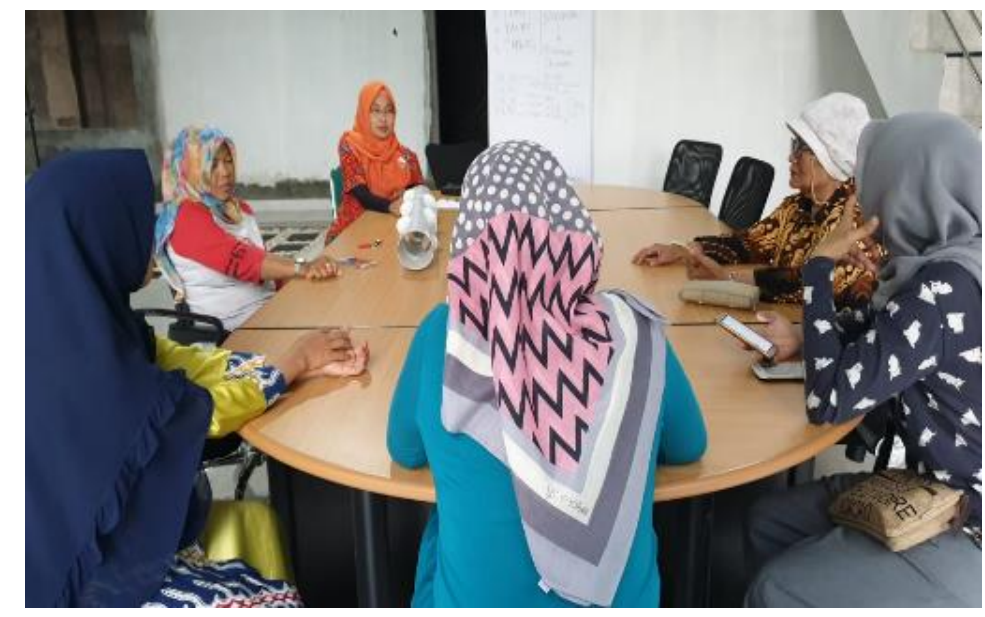

Pembentukan keluarga berdaya (Sumber: dokumen pribadi, 2020). 


\section{Pendampingan Gerakan Keluarga Berdaya}

Selanjutnya pemberdayaan masyarakat ini juga bersandar pada paradigma Sustainable Development (UNDP, 2016), bahwa pembangunan berkelanjutan memperhatikan aspek ekonomi, sosial dan lingkungan. Mutiarin (2017) menjelaskan bahwa pemberdayaan dan pembangunan pembangunan harus memberi manfaat untuk kelompok sasaran. Oleh karena itu pendampingan Gerakan Keluarga Berdaya PKK Dasawisma IV dilakukan intensif selama 4 bulan oleh tim UMY. Dimulai bulan Januari 2020 sampai dengan bulan April 2020.

\begin{tabular}{|c|c|c|}
\hline Pendampingan & Keterangan & $\begin{array}{l}\text { Penanggungjawab } \\
\text { kegiatan }\end{array}$ \\
\hline $\begin{array}{l}\text { 1. Identifikasi dampak ekonomi } \\
\text { covid pada keluarga }\end{array}$ & Identifikasi penghasilan keluarga yang menurun sejak januari 2020. & Ketua dasawisma \\
\hline $\begin{array}{ll}2 . & \text { Pengenalan potensi dan } \\
& \text { sumberdaya milik keuarga }\end{array}$ & $\begin{array}{l}\text { Anggota mengidentifikasi potensi lahan di rumah, botol bekas } \\
\text { untuk menanam sayuran, jenis sayuran yang sesuai. }\end{array}$ & Sekretaris dasawisma \\
\hline $\begin{array}{l}\text { 3. Pemanfaatan lahan pekarangan } \\
\text { untuk ketahanan keluarga }\end{array}$ & Menyiapkan lahan dan tempat untuk menanam sayuran & Humas dasawisma \\
\hline 4. $\quad$ Nilai tambah ekonomi & $\begin{array}{l}\text { Menghitung selisih antara hasil menanam sayuran dengan belanja } \\
\text { yang dapat dihemat. }\end{array}$ & Bendahara dasawisma \\
\hline
\end{tabular}

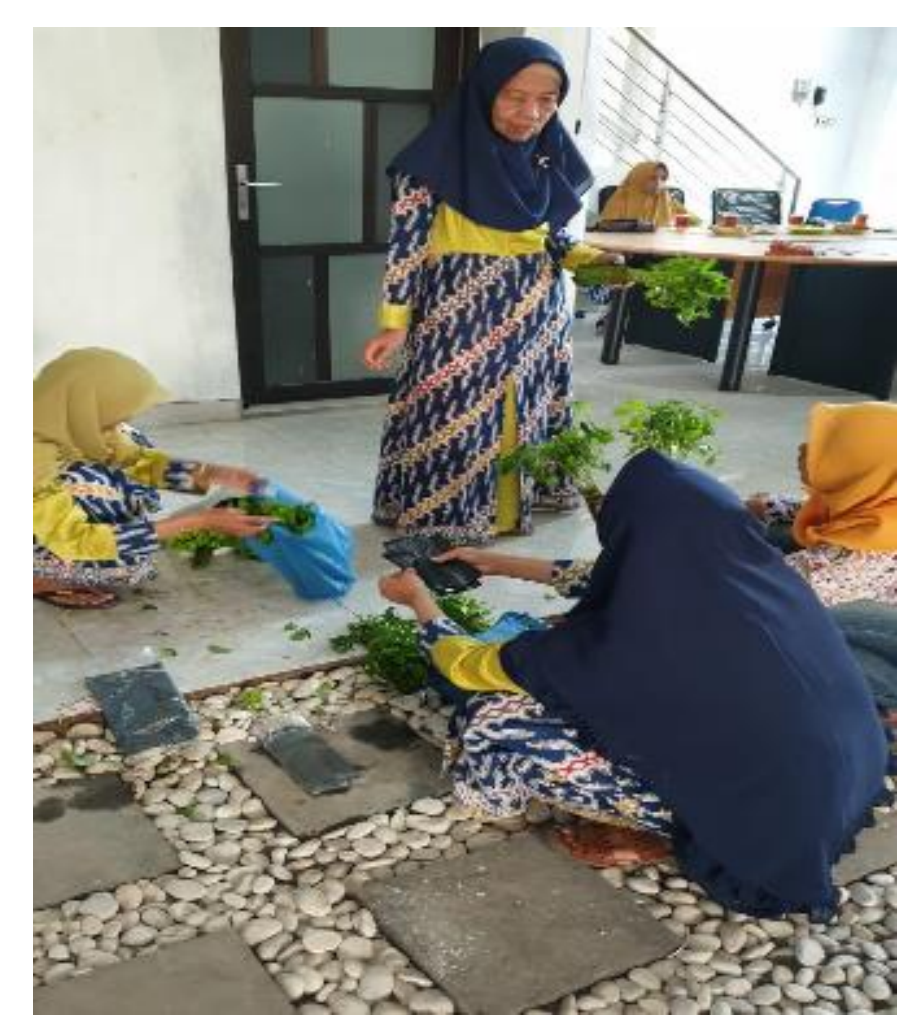

Pendampingan Kegiatan Keluarga Berdaya (Sumber: dokumen pribadi, 2020)

(4). Pemberian fasilitas hidroponik untuk Gerakan Keluarga Berdaya

Korten (2002) menyatakan upaya untuk melaksanakan pembangunan yang berpusat pada raktyat dilakukan melalui pemberdayaan. (Payne, 1997, h. 266), Ife (1995, h.182) dan Sutrisno (2000, h.185) memberikan batasan pemberdayaan sebagai upaya penyediaan kepada orangorang atas sumber, kesempatan, pengetahuan, dan keterampilan, masyarakat diberi wewenang untuk mengelola sendiri dana pembangunan baik yang berasal dari pemerintah maupun dari pihak lain. 


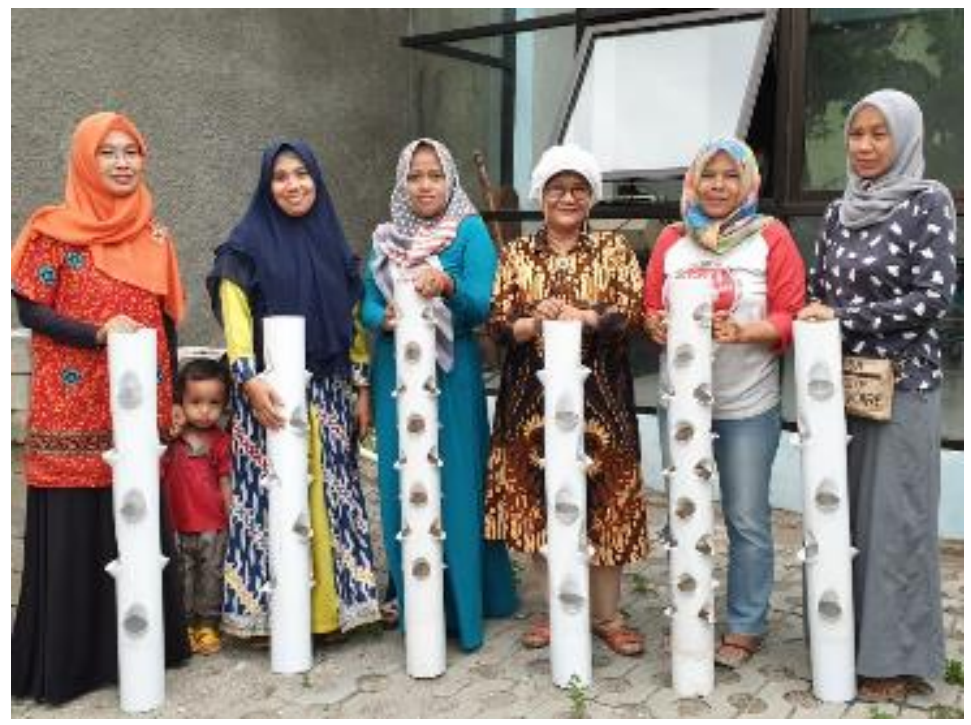

Pemberian fasilitas hidroponik (Sumber: dokumen pribadi, 2020)

Dalam kegiatan pemberdayaan ini, Tim UMY juga memfasilitasi kelompok Dasawisma IV Maguwo Banguntapan dengan alat penanaman hidroponik. Dalam hal ini, pemberdayaan bersifat partisipatif. Pemberdayaan masyarakat bertujuan untuk meningkatkan potensi masyarakat agar mampu meningkatkan kualitas hidup yang lebih baik bagi seluruh warga masyarakat melalui kegiatan-kegiatan swadaya.

\section{Simpulan}

Target yang diharapkan dari program pengabdian masyarakat Pemberdayaan Perempuan Melalui Keluarga Berdaya PKK Dasawisma Maguwo Banguntapam di Masa Pandemi Covid-19 ini adalah berupa terbentuknya keluarga berdaya dan meningkatnya kemampuan ekonomi dalam masa pandemi covid-19.

Selanjutnya program mampu membentuk keluarga berdaya. Program Mengidentifikasi permasalahan keluarga berdaya untuk :
a. Keluarga mampu mengenali potensi yang ada disekitarnya untuk dijadikan kegiatan produktif.
b. Mengenalkan dunia usaha pada keluarga.
c. meningkatkan kegotongroyongan dan kerukunan antar anggota dasawisma
d. menambah pengetahuan dan ketrampilan menuju ekonomi produktif
e. Meningkatkan ekonomi keluarga

\section{Ucapan Terima Kasih}

Penulis mengucapkan terimakasih kepada :

1. LP3M UMY dengan SK No. 031/PEN-LP3M/I/2020

2. Kelompok IV Dasawisma Maguwo Banguntapan

\section{Daftar Pustaka}

Dyah Mutiarin, Sakir Sakir, Titik Sunarti Widyaningsih. 2017. Peningkatan Daya Saing TK ABA Berbasis Penguatan Organisasi dan Teknologi Informasi Melalui Program Sister School, Jurnal Berdikari, Vol 5, No 2 (2017), halaman 116-125

Hartono, Hartono \& Widjanarko, Bagoes \& EM, Mexitalia, 2017. Hubungan perilaku Keluarga Sadar Gizi (KADARZI) dan Perilaku Hidup Bersih Sehat (PHBS) pada tatanan rumah tangga 
dengan status gizi balita usia 24-59 bulan. JURNAL GIZI INDONESIA. 5.88. 10.14710/jgi.5.2.88-97.

Ife, Jim. 1995. Community development: Creating Community Alternatives-Vision Analysis And Practice, Australia, Longman Pty Ltd.

Manzon, Maria . 2017. Comparative education as a field in Asia: retrospect and prospect Asia Pacific Journal of Education, Volume 37, 2017-Issue 3.

Payne, Malcolm. 1997. Modern Social Work Theory. Second edition London.

Soetrisno, Loekman. 1997, Kemiskinan, Perempuan, Pemberdayaan, Yogyakarta: Kanisius.

Sudjana, D. 2000. Pendidikan Luar Sekolah, Wawasan, Sejarah Perkembangan, Falsafah,Teori Pendukung, Asas. Bandung: Falah Production.

http://pemdesbanguntapan.blogspot.com/p/peta-desa.html

https://www.suara.com/lifestyle/2018/11/30/113945/data-bps-orang-indonesia-

makan-buah-dan-sayur-hanya-173-gram-per-hari

https://www.un.org/sustainabledevelopment/development-agenda/ 